\title{
Seeing is Believing: Miniature and Gigantic Architectural Models of Second Temple
}

\begin{abstract}
:
Miniature architectural models are often used as signs or markers, which frame a touristic site as a place worth visiting. In this paper I explore the relations of such models to the 'real' sites, as well as to other copies and representations. The article examines the Holyland Model, a miniature model showing Jerusalem in the year 66 $\mathrm{AD}$, which has become a tourist site in its own right. The central building in this model is the miniature Jewish Temple, which was later replicated in both miniature and gigantic copies. I follow the transformation of this Temple image, from a secularcultural symbol of Israeli national identity to a represention of different Orthodox Jewish and Christian evangelical agendas. I argue that the large-scale buildings in fact replicate the miniature models, inverting both sign relation and scale relation between original and copy. The use and manipulation of the image of a building, produced initially at the Holyland Model, has become an essential device for the production of meaning and affect.
\end{abstract}

Key words: architectural models, Temple, miniature, gigantic, copy.

\section{Introduction}

This paper examines architectural models and their relation to their referent full-scale buildings. Miniature models are cultural material artifacts, used in order to present the visitors with specific versions and interpretations of the exterior world. For the tourist, miniature models represent the toured country, or some of its highlights, in a condensed spatial and temporal form. They mark sites as tourist attractions, which are then recognized by the visitors. Importantly, the process of recognition is essential in order for the tourist to make sense of the touristic experience.

Miniature representations act as 'off-site markers', which frame the 'real' sites as original or authentic (MacCannell, 1976, pp. 111-117). The authentic sites must be marked and differentiated using representations, because authenticity is a sign relation (Culler, 1988, p. 160). However, I will argue that the relation between 'marker' and 'real site' is more complex. To discuss this relation I will use Max Black's definition of a model as a three dimensional, more or less true to scale, representations of an 
existing or imagined material object (Black, 1962, p. 219). Following this definition, I will question the point in which a model becomes a building, considering its scale, its representational qualities, and to what extent it has an independent existence of its source object.

The four cases that I examine include two miniature models of the Jewish Second Temple, located in Jerusalem, which were produced as markers of the absent ancient shrine: The Holyland Model, and the Temple Model at Aish HaTorah Yeshiva. The two other models of the Temple are large-scale buildings: the Great Temple at Florida's Holy Land Experience is a scaled-down version of the 'original' Temple; and Solomon's Temple at Sao Paulo, Brazil, is even larger than the original. My argument is that the large-scale buildings in fact replicate the miniature models, inverting both sign relation and scale relation between original and copy. They raise questions concerning scale and representation: what is the relation of miniature representations to the full-sized referent? How do large-scale buildings replicate their models? Can these buildings then be termed models?

To answer these questions I refer to Bill Brown's Thing Theory. Brown suggests that we look through objects, or take them habitually for granted. He argues that objects turn into 'things' when they cannot pass unnoticed. This can happen when objects disfunction, break down or stop working, causing a shift in our perception: 'The story of objects asserting themselves as things, $[\ldots]$ is the story of a changed relation to the human subject and thus the story of how the thing really names less an object than a particular subject-object relation' (Brown, 2001, p. 4). Further, Brown argues that 'things' are 'what is excessive in objects', and can be imagined as 'what exceeds their mere materialization as objects or their mere utilization as objects - their force as a sensous presence or as a metaphysical presence, the magic by which objects become values, fetishes, idols and totems' (Brown, 2001, p. 5).

Throughout this article I will suggest that miniature models refer to external 'objects', and by doing so, they assert themselves as 'things'. By posing the visitor in front of a miniature version of a building, scale relations are inverted: rather than being dwarfed by a building, the visitor is empowered over its miniature. The habitual subject-object (or body-building) relations are changed. The model is recognizable as a reference to a specific full-scale building, but it does not function as a space that encloses the body. Brown emphasizes 'the simultaneity of the objectlthing dialectic, and the fact that, all at once, the thing seems to name the object just as it is even as it 
names some thing else' (Brown, 2001, p. 5, original emphasis). The model names the building, but it also names itself as a separate entity, which is both a marker of the 'real' site (the building, 'object') and an artifact ('thing'). Indeed, in the cases explored in this article, the full-scale buildings gain their state of 'thingness' because they are replicas of the miniature objectlthing. Thus both the miniature and the full-scale buildings inspired by it, all mark and indicate the ancient Temple as 'real'.

The article concludes by comparing the qualities of miniature and gigantic Temple representations, and the ways in which scale is used as a tool in communicating narratives of collective identity, belonging, and 'geopiety'. The term 'geopiety' was used by Tuan (1976) to describe human attachment to place, and later by Long to indicate 'that curious mix of romantic imagination, historical rectitude, and attachment to physical space' (Long, 2003, p.1). I will examine the power of these replications to construct both physical and imagined realities, and to produce and re-produce meaning and affect.

\section{The Holyland Model}

The Holyland Model (fig.1) is a miniature model (scaled 1:50) of ancient Jerusalem, designed and built between 1962-1966, on the grounds of the Holyland Hotel in Jerusalem. It represents Jerusalem at the time of the Jewish Second Temple, in the year $66 \mathrm{AD}$, when the city was at its greatest geographic extent and at the high point of Jewish independence, shortly before its destruction by the Romans in 70 AD (Tsafrir, 2009, p. 9). This period is of central importance in the Zionist ethos, which emphasizes its connection to symbols of national independence during biblical times (Liebman and Don-Yehiya, 1983, p. 37). It is also significant for Christians, as the time and city of Jesus. The Holyland Model is a well-known site in Israel and has been widely studied. ${ }^{\text {ii }}$

At the time of the model's construction, Jerusalem was divided by a border, drawn following the 1948 war. Most of the city's historical and holy sites, located in and around the Old City, were under Jordanian rule, and Israelis had no access to them. This geo-political situation had detrimental effects on the city's economy and particularly on the sector of tourism. Indeed, the Holyland Hotel was one of the only hotels built in Israeli West Jerusalem around this period (Cohen-Hattab and Shoval, 2015, pp. 118-119). 
The founder and owner of the Holyland Hotel, Hans Kroch, wanted a cultural and tourist attraction for his hotel, which was located quite a distance away from any particular site of interest. He decided to commission the model, which was to form 'a link between the magnificent Jerusalem of the past and Jerusalem of today' (Ribon, 1965). Kroch was concerned about West Jerusalem, which was cut off from its ancient origins and historic monuments: 'We are missing what Rome and Athens have - ancient buildings', he told a journalist in 1965 (Ribon, 1965). Kroch decided to recreate the missing historical sites in the model. His declarations echoed the secular Zionist narrative that goes back to Second Temple in linking the Jews to the territory of contemporary Israel. He is quoted as saying: 'if Jews cannot get to the holy places, the holy places will come to them' (Cherni and Tsafrir, 2009, p. 14).

Kroch approached Professor Michael Avi-Yonah, a scholar of classical archaeology at the Hebrew University, who specialized in the period of the Second Temple, and asked him to design the model (Tsafrir, 2009, p.9). His wife Hava AviYonah, an artist, made the working drawings. Planning the model was a complicated task, since Michael Avi-Yonah decided to show the city in its entirety, even if this meant compromising scientific accuracy (Tsafrir, 2009, p.12). Since there was no access to the sites, the design had to rely on earlier excavations, ancient texts, Jewish sources and the New Testament (Cohen-Hattab and Kerber, 2004, p.67), and on Hellenistic and Roman archaeological sites around the Mediterranean (Lavie, 1964; H. Avi-Yonah, personal interview, February 24 2010).

One of the central features of the Holyland Model is its appeal to the visitors as authentic and accurate. Although it is a creative representation rather than an original object, it has always had a reputation of a scientific and authoritative reconstruction of ancient Jerusalem. As a representation of archaeology, it is part of the legacy of archaeology in Jerusalem, which is closely connected to the political context. The modern archaeological study of Jerusalem has been used over the past two centuries as a tool to pursue and to demonstrate 'essences' of origin as well as national roots (Silberman, 2001, p. 501).

The model was intended to provide its visitors with a sense of identity and meaning, by constructing a link between people, country and history. Its miniature geography of remains played a part in representing the modern nation as a continuous existence in time and space, using the past as a source of common history and collective 
memory. Moreover, the Holyland Model also gave shape to a longing for Jerusalem's future unification.

This longing was fulfilled when Israel conquered the Old City and East Jerusalem in the 1967 war, and the ancient sites became accessible to the national collective. In this new context, the Holyland Model retained its significance as a popular site, because paradoxically its representation of the entire ancient city is easier to comprehend than the actual ruins that were excavated on site.

In 2006 the grandson of Kroch, now the owner of Holyland Tourism Company, decided to make new development and construction plans for the site. The Holyland Hotel was demolished, and the model was relocated to the Israel Museum (fig. 2). This is the largest museum in Israel, located in Jerusalem next to the parliament and government buildings. It houses some archaeological artefacts, which date back around the time represented in the model. The relocation of the Holyland Model from the hotel to the context of the Israel Museum has greatly enhanced its status as both a national exhibit and a scientifically accurate representation (Padan, 2017a; Chapter Three).

Due to its reputation as an authoritative reconstruction of ancient Jerusalem, the Holyland Model, and particularly its Temple building, has inspired the construction and exhibition of many other Temple models, both miniature and full-sized. In the following sections, three of these models will be discussed.

\section{The Temple Model at Aish HaTorah Yeshiva aii}

The model on the roof of Aish HaTorah Yeshiva is one of several recent Temple models located in different institutes operating in Jerusalem, ${ }^{\text {iv }}$ and influenced by the Holyland Model. Balakirsky Katz suggests that the proliferation of such models has to do with the relocation of the Holyland Model. She argues that the move to the Israel Museum has altered the model's meaning for Orthodox Jews: whereas in the context of the hotel, they perceived the model as a recreation of a Jewish religious site, the move to the museum had changed its meaning into an Israeli cultural object (Balakirsky Katz, 2011, pp. 355-6). She points out that some Orthodox religious leaders reject the museum, not merely because it displays non-religious art, but also because it reflects a secular approach to Jewish identity in terms of culture rather than religion. For these leaders, the museum cannot house the Temple, since they perceive the Temple itself as the shrine that should house the Jewish treasures (Balakirsky Katz, 2011, p. 358). 
The relocation of the model therfore influenced the decision of Orthodox institutions to commission and display other models of Second Temple. Within such institutions, the Temple models are viewed in a context that focuses on the centrality and authority of religion in Jewish national life. Religion, rather than culture, is viewed as defining the Jewish State (Balakirsky Katz, 2011, pp. 357-8).

The model at Aish HaTorah Yeshiva (fig. 3) was commissioned from Michael Osanis, who had built two smaller Temple models previously. His first model was inspired by a dream, which he described in a newspaper interview. In his dream, Osanis looked into the past and saw the ancient Second Temple, and then glimpsed into the future:

Behind the horizon that heavenly light shone all over the sky. [...] I understood this is the light of the next Temple, which is not so far from today. I came to the conclusion: I must pass on what I have been shown. (Bruckner, 2010)

Having no previous experience in model building, Osanis spent six months building his Temple model. Rabbi Israel Ariel, head of the Temple Institute, ${ }^{\mathrm{V}}$ was impressed by the model and commissioned Osanis to build another larger and more detailed one. This led to the commission of a third model from Osanis, this time by Aish HaTorah Yeshiva, in 2009.

This model, at a scale of 1:60, was placed on the roof terrace of Aish HaTorah Yeshiva in the Old City of Jerusalem. There, the model is viewed with the Muslim Shrines on the Temple Mount in the background. It faces the historic location of the ancient Second Temple on the Temple Mount. Its position suggests the model and - by extension - its source-object, as a tangible alternative to the mosques. Indeed, Osanis perceives it as a step towards the rebuilding of the Third Temple (Bruckner, 2010).

The differences in context and location between the Holyland Model and the model at Aish HaTorah Yeshiva exemplify a shift in the use of Temple models. While the Holyland Model represents secular interest in archaeology as a link to modern Israeli cultural and national identity, its replications represent a view in which the Temple is a symbol for Jewish Sovereignty over the Holy Land, part of an ethnonational project (Persico, 2017, p. 115), which includes a religious search for spiritual, halachic, nationalist or messianic sentiments (Be'er, 2013, p. 24). 
I have argued previously ${ }^{\mathrm{vi}}$ that the Aish HaTorah model is therefore perceived in the context of the religious and political nationalist sentiments surrounding the Temple Mount and the Temple itself in contemporary Israel. As argued by Persico, the merging of political nationalism and religious messianic thought threatens to undermine the Zionist project of secular nationality and democracy: 'it is the end point of Zionism - the point at which Zionism self-destructs' (Persico, 2017, p. 113). I suggest that the model at Aish HaTorah Yeshiva, wiewed with the Mosques in the background, offers a material representation of this possibility.

Aish HaTorah Yeshiva presents the model as a didactic tool, explaining that 'This model helps people envision what it was like to be here at the time of the Temple' (Simmons, 2010). It thus tries to avoid the sensitive political and religious issue of the Temple Mount. But this issue cannot be avoided, as seen in photos of the model on the Aish.com website in a section called 'Today's Israel Photo', showing various sites and scenes from Israel. One photo of the model is captioned: 'Third Temple Model' (http://www.aish.com/photos/326207281.html?s=srcon). Another photo of the model has this text: 'A beautiful replica of the Holy Temple on the rooftop of the Aish World Center, overlooking the real spot of the Temple, may it be rebuilt soon in our days!'(http://www.aish.com/photos/?date=Tammuz_18).

\section{The Temple model at the Holy Land Experience}

A religious interest in the Temple and a messianic longing for its rebuilding is also central to evangelical Christianity. It is evident at the Holy Land Experience in Orlando, Florida (fig. 4). This site, described on its website as a 'living biblical museum' (https://www.holylandexperience.com/about/), seeks to combine a physical and spiritual experience using lage-scale replicas of sites from Jerusalem, including the Second Temple:

It is a living, biblical museum that takes you 7000 miles away and 2000 years back in time to the land of the Bible. Its combination of sights, sounds, and tastes will stimulate your senses and blend together to create a spectacular new experience.

But above all, beyond the fun and excitement, we hope that you will see God and His Word exalted and that you will be encouraged in your search for enduring truth and the ultimate meaning of life. (https://holylandexperience.com/about/) 
The Holy land Experience (HLE) was initiated by Marvin Rosenthal, a Jew who had converted to Christianity as a teenager and became a minister in 1968 (Spalding, 2002, p. 14). He is the founder of Zion's Hope, Inc., a Christian ministry active in converting Jews, which initiated the HLE as a non-profit evangelical ministry. On the website of Zion's Hope (http://www.zionshope.org), its aim is clearly stated:

\footnotetext{
Zion's Hope seeks to graciously proclaim to the Jewish people their need for personal salvation through Jesus the Messiah and to proclaim the gospel of the Lord Jesus Christ to all men regardless of race, religion, gender, education, or national origin.
}

In 1989 Rosenthal purchased a 15-acre site in Orlando, situated next to world famous theme parks such as Disney World and Universal Studios. His vision for the site, as stated on the HLE website, was to 'proclaim the Gospel to as many people as possible; and to help believers have a better understanding of the Judaistic roots out of which Christianity grew'(https://holylandexperience.com/history/).

The vision was realized at an investment of $\$ 16$ million. The park was designed and constructed by ITEC Entertainment Corporation, whose projects include theme parks, rides and shows, resorts and entertainment centers. As explained on the ITEC website: 'visitors of themed environments seek experiences that excite their senses and enrich their lives beyond imagination. ITEC meets those challenges by turning dreamlevel concepts into real facilities and experiences' (http://www.itec.com).

The park's opening in 2001 aroused protests from local Jewish leaders (Usborne, 2001). The Jewish Defense League described Rosenthal as a 'soul snatcher' and protested against 'the spiritual destruction of the Jewish people' (Brabant, 2001). In 2007 the Holy Land Experience was purchased by the Christian Trinity Broadcasting Network (TBN), which currently owns and runs it.

Within and around the sites replicated in the park, dramatic performances and musicals are staged; the buildings provide a backdrop or house the productions. The HLE website (https://holylandexperience.com/about/) declares:

Recreations of the ministry of Jesus, stories from the Old Testament, miracles and triumphs, and the story of musical praise through the ages will all move your spirit and emotions in praise to our Lord God. 
The performances and the spaces both shape the performance-viewing experience for the visitors (Stevenson, 2013, p. 98). Rather than mere entertainment, these are powerful religious tools. As argued by Stevenson:

\footnotetext{
Evangelical dramaturgy tries to situate the physical encounter between object/event/space and believer as central to religious meaning-making. In doing so, the re-representation reinforces evangelical theology, in particular the notion of direct access to an incarnate divine presence. (Stevenson, 2013, p. 39).
}

By moving within the spaces and attending live shows the visitor creates an experience of a personal journey or pilgrimage. This experience differs from the detached overall view experienced at the miniature models discussed previously. Here the models engulf and affect the body: 'From the moment you pass through the gates of our walled city, you will be immersed in ancient Jerusalem.' (https://holylandexperience.com/about/). The abstracted journey is therefore based on the experience of the moving body travelling through space and time. The authenticity of this imagined landscape is achieved by simulating the 'original' building materials, described on the HLE website:

Then at the grand entrance to the Temple Plaza, walk under a massive archway and behold the gleaming white stone plaza surrounding you with its thirty Roman columns crowned with gold capitals. All this grandeur majestically frames the imposing Great Temple, the place held in highest reverence among the Jewish people.

(https://holylandexperience.com/about/).

The Temple is indeed a dominant feature of the park (fig. 5). The website further explains that this structure is a half-size scale model which provides 'an accurate depiction of Herod's Temple'. Although this is a scaled-down model, it is large enough to be an imposing six-story-high building. Inside is an auditorium called 'The Theater of Life', where a video outlines human history from the viewpoint of evangelical Christianity. Outside the building, Christian dramas are performed daily, with the Temple and its entrance court framing the scenes (Branham, 2008, p. 24).

As argued by Wharton, the centrality and size of this Temple is indicative of the Temple's place in evangelical eschatology, as well as of evangelical Christianity's commitment to the construction of a new Temple (Wharton, 2006, pp. 224-225). Is it 
a building, or a model? Its size certainly means that this is no miniature model. Nevertheless, it draws its meaning from a source-object, and it is a scaled-down version; both of these features characterize models.

Another feature of models is their temporal reference: some represent buildings that existed in the past, while others represent contemporary buildings or envision (in the present) future buildings yet to be built. The Temple model at HLE allows the visitors to journey back to ancient Jerusalem, but also offers a vision of the future by representing the restored Jewish Temple (Stevenson, 2013, p. 54). Indeed, this future Temple is the same Third Temple that Michael Osanis aspires to build.

\section{Solomon's Temple, Sao Paulo, Brazil}

Solomon's Temple houses the headquarters of the Universal Church Kingdom of God (UCKG). This megachurch (fig. 6) has 10,000 seats, and includes within its 74,000sqm complex many other functions: a Bible School with classrooms for 1300 children, offices, television and radio studios, and apartments for the priests and for the founder and leader of UCKG, Bishop Edir Macedo. The building is much larger than the 'original' ancient Jerusalem Temple. It took four years to build, at a cost of about $\$ 300$ million (Romero, 2014), and was inaugurated in July 2014.

In an interview with him on the UCKG blog in 2012 (http://uckgtempleofsolomon.blogspot.co.uk), Macedo explained that a visit to Jerusalem had inspired him to build a Temple in Sao Paulo, which would provide a spiritual experience to its visitors by imitating the Jewish Temple:

The Temple of Solomon could be built - its replica - here in Sao Paulo. The people could have access to a historic place, extremely spiritual, because it's where God manifested himself, we could say physically, to all the people and Children of Israel in that time.

Blurring the differences between the ancient Temple ('a historic place' from 'that time') and its replica, makes the new Temple a spiritual place, like its referent. Its 55-meter high façade is clad with Jerusalem stone, imported from Israel, thus symbolically importing part of the holy land to Sao Paolo. As noted by Macedo in a televised service, the stones are 'just like the ones that were used to build the temple in Israel; stones that were witnesses to the powers of God, 2,000 ago. The outside will be exactly the same as that which was built in Jerusalem.' (Quoted in Philips, 2010). 
The size and appearance of Solomon's Temple serve not only spiritual aims, but also express some wider changes taking place with the growing influence of evangelical Christianity. As argued by Casanova, Pentecostalism (of which UCKG is a branch), is a highly decentralized religion, with no historical links to tradition and no territorial roots or identity (Casanova, 2001, p. 434). I suggest that Solomon's Temple, which is visually linked with the Old Testament and Judaism, is meant to provide a tangible symbol of tradition and territory.

Latin America, which was formerly a Catholic territory, has become a world center of Pentecostal Christianity, and the number of believers has grown rapidly in the past 40 years (Casanova, 2001, p. 437). It is estimated that in Brazil numbers have grown from $5 \%$ of the population in 1970 , to $22 \%$ of Brazil's 200 -million population in 2014 (Watts, 2014). Using TV and radio channels (such as Rede Record, owned by Macedo, which is the second largest TV company in Brazil), these churches have gained significant political power and influence. The UCKG, which was founded in 1977, had 1.8 million members in Brazil by 2010 (Romero, 2014). Solomon's Temple positions it as a leading congregation within Brazil's evangelical Christian population.

In spite of the imported building materials, the Sao Paulo Temple differs considerably from the ancient Temple which was built by King Solomon in 960 BC and destroyed in 587 BC (Reiter, 2001, p. 7). There are no physical remains of this temple, but Morrison argues that the Sao Paolo Temple bears no resemblance to the Biblical descriptions, dimensions or details of Solomon's Temple. Thus, neither the external structure nor the interior of the Biblical Temple of Solomon is replicated in Sao Paolo (Morrison, 2013, pp. 1-3). Solomon's Temple at Sao Paolo was designed by architect Rogerio Silva de Araujo, and the UCKG blog (http://uckgtempleofsolomon.blogspot.co.uk), explains the planning considerations:

Redisigning the King Solomon Temple from the Bible quotations became a big challenge - from the time we had the initial understanding that the scale used by Solomon would not meet the need of the UCKG for today. Moreover, at that time, only the priests could attend it, but this has not applied to the Temple we are building, seen that not only church members but also anyone interested may have the opportunity to go back in time and learn a little more of this amazing project.

Furthermore, Macedo had described the Jerusalem stones as referring 2000 years back, and this was the time of Second Temple built by King Herod (begun 19 
BC), rather than of King Solomon's First Temple. Morrison therefore maintains that the Sao Paulo Temple replicates Herod's Temple (Morrison, 2013, p. 3). Indeed, I argue that the Sao Paolo Temple resembles the Holyland Model's Second Temple.

What is the reason for this resemblance? Arguably, there are more images available of Herod's Temple than of Solomon's Temple, making its replication an easier task (Abascal, 2014). Morrison suggests further reasons:

\footnotetext{
The architecture of Herod's Temple was grander, richer and larger than the Biblical description of Temple of Solomon. However, Herod had a reputation as a corrupt and ruthless tyrant who murdered his rivals [...] On the other hand, Solomon and his Temple symbolize wisdom, justice and piety. Bishop Macedo does not mention Herod and only refers to the Temple of Jerusalem or the Temple of Solomon and he makes no distinguish between the two. By writing the narrative of the Temple of Solomon into the architecture of Herod, Bishop Macedo achieves an image of the grand architectural history of Herod whilst claiming the political and the religion legacy of King Solomon. (Morrison, 2013, pp. 5-6).
}

Consequently, in media coverage of the building process and inauguration of the Sao Paolo Temple, the name 'Solomon's Temple' (referring to the First Temple) is becoming associated with the image of Herod's Temple (which is the Second Temple, built about six hundred years after the destruction of Solomon's Temple). As a result, these two distinct Temples are becoming merged in the public imagination (Morrison, 2013, p. 4).

As I suggested above, the Sao Paolo Temple replicates the Holyland Model Temple, but rather than being a miniature model (as in Aish HaTorah Yeshiva), or a scaled-down model/building (as in HLE), it is much larger than Herod's Temple. Can it be termed a model? Considering Max Black's definition of a model, the Sao Paolo temple is a three dimensional, more or less true to scale, representation of an existing or imagined material object. In fact, its meaning depends on its referent object - the miniature Holyland Model, whose meaning in turn depends on its claim to accurately represent Herod's Temple.

\section{Discussion: the miniature and the gigantic}

Going back to Brown's Thing Theory, I define the miniature Holyland Model Temple as a transitional 'thing', which not only represents the historic object, but also inspires 
its translation back into a building. As seen here, aspirations to rebuild the Temple are evident both in Jewish messianic actions, and in the Christian sites discussed.

The larger replications of the Temple thus go a step closer to the original, by simulating its reconstruction as a building. They materialize a vision, that precedes an anticipated building, using the image of the ancient one. This simultaneous reference to the past and to the future characterizes 'things', as defined by Brown: 'Temporalized as the before and after of the object, thingness amounts to a latency (the not yet formed or the not yet formable) and to an excess (what remains physically or metaphysically irreducible to objects)' (Brown, 2001, p. 5).

Scale and its relation to the body is a dominant feature in both the miniature and the gigantic replications. Stewart points out that our means to understand scale was traditionally the human body, and that 'the domain of immediate lived experience' can only take place in the space occupied by the body (Stewart, 1993, p. 101). This determines the relation of the body to both the miniature and the gigantic: 'The miniature allows us only visual access to surface and texture; it does not allow movement through space. Inversely, the gigantic envelopes us, but is inaccessible to lived experience' (Stewart, 1993, p. 102). Stewart further argues that the miniature moves from our hand, which can hold it, to our eye, to abstraction and distancing. The gigantic, on the other hand, 'moves from the occupation of the body's immediate space to transcendence (a transcendence which allows the eye only imperfect and partial vision) to abstraction' (Stewart, 1993, p. 102). I suggest that indeed both the miniature and the gigantic replicas of the Temple discussed here exemplify this notion of distancing from the body and moving towards the abstraction of ideologies, prophecies and visions.

The HLE Temple is large in relation to the body, and even more so in comparison to the miniature model that inspired it. But it nevertheless retains close resemblance, and derives meaning, from the miniature Holyland Model. The HLE Temple is therefore both an exaggerated copy of the Holyland Model, as well as a largescale (but still miniature) model of the ancient Herod's Temple. Its significance lies in referencing both structures, and this is emphasized by its location within a theme park, a genre in which buildings are replicated in order to create the themed setting. Further, as argued by Stevenson, the theme-park configuration is essential because it is a recognizable and friendly genre: 
Visitors to HLE are prompted to live in a theme park \Christian Holy Land blend that is easy to use, contemporary and, with its Disney-like features, in some respects uniquely American. Their experience navigating and using this familiar, accessible Holy Land constructs an intimate script that is comfortable, comforting and pertinent. And, like all intimate scripts, it serves to verify the certainty of particular beliefs, in this case the crucial, inviolable importance of Christianity to the Holy Land. (Stevenson, 2013, p. 118).

At the HLE, both the miniature and the gigantic are present, since the park also includes a miniature model of the entire first-century city of Jerusalem. Like the HLE Temple, this model is also reminiscent of the Holyland Model. Unlike the imagined landscape of the park, which is composed of select replicas irrespective of the 'real' geography, this model provides the physical context by giving an overview of Herod's Jerusalem:

\footnotetext{
Visit our model, the largest indoor replica in the world, and see where Jesus walked, ministered, healed, and performed other miracles. Marvel at the massive Temple where the sacrifices took place. Follow the steps that Jesus took from the Upper Room to Calvary and the empty tomb. Enjoy the historical presentation of this ancient city by one of our knowledgeable lecturers. Admire the hand-crafted, life-like figurines, and feel almost as if you are in the city itself. (HLE website: https://holylandexperience.com/exhibit/jerusalemmodel-a-d-66/).
}

While the Holylnd Model shows the entire platform surrounding the Temple, at the HLE some of the Temple Mount has been modified. In place of its southern part there is a lowered area where guides stand while explaining the model. Wharton points out that this part of the platform, which was left out, happens to be the location of today's al-Aksa Mosque (Wharton, 2006, p. 225).

Whereas the miniature is grasped as a whole, the gigantic can only be seen in its entirety from a distance. It is experienced in fragments and parts, exposed one by one, introducing a temporal dimension (Stewart, 1993, p. 79). The architect of Solomon's Temple, Rogério Araújo, has declared: 'We sought to build a colossus, something that would make people stop and gaze, and that's what we delivered.' (Quoted in Romero, 2014). Araújo added a theological explanation for the size of the building: 'We made a larger project in reference to the passage of Haggai, Chapter 2.9, which says, "The glory of this latter house shall be greater than the one of the former", (Quoted in Abascal, 2014). Nevertheless, the Universal Church website atresses: 'This 
project is only a replica, not the third temple.' (http://web.universal.org/usa/temple-ofsolomon-gods-altar-on-earth/).

Rather, Solomon's Temple is characterized by features of contemporary megachurches: Protestant affiliation, immense size, modern appeal, and technological sophistication, which create a powerful devotional experience (Stevenson, 2013, pp. 225-226). Such churches typically have amphitheater tiered seating, large projection screens, and sound systems, allowing church leaders to 'craft precise sensual encounters for worshippers' (Stevenson, 2013, p. 185), I argue that at Solomon's Temple this experience is enhanced by using the image of (Herod's) Temple established at the Holyland Model. The discourse of the relation between the church and the Temple of Jerusalem prepares the visitor to enter a holy space, which symbolizes historical continuity and a link with the Jewish roots of Christianity, as well as a longing for the rebuilding of the Temple that will bring about the coming of the Messiah (Wharton, 2006, p. 223).

The Sao Paulo Temple has inspired a video artwork made by artist Yael Bartana, entitled 'Inferno', which was shown in the 31st Bienal de Sao Paolo in 2014. It visualizes the inauguration of Solomon's Temple with a grand ceremony, followed by its destruction. 'Inferno' recalls the short existence of Herod's Temple, destroyed by the Romans less than a decade after its completion. The impact of Solomon's Temple on the artist is explained in the exhibition guide:

\footnotetext{
On a visit to the construction site of what would become the third version of Solomon's Temple - this time in Sao Paulo - Bartana could envision no other possible future than the prophetic repetition of the past - in other words, its destruction. In what she calls a 'pre-enacting', the artist documents, between the forgetting and celebration of a fantasized past, the way that history is written and religions are founded. (Seroussi, 2014)
}

The idea of the Temple is powerful, whether as a symbol of secular Israeli national identity, of Jewish sovereignty, or of evangelical redemption. As I have illustrated throughout this article, the tangible representation of the idea of the Temple is its well-known image established at the Holyland Model. I conclude that the miniature models representing the Temple buildinglobject, and the gigantic buildings representing the Temple modellthing, continuously interact to produce both imagined and concrete subject-object relations and meaning. 
References

Abascal, I. M. (2014). Translating Sacred Architecture: Solomon's Temple in Sao Paulo. The Avery Review, no. 4.

Abramson, L. (2006). A Pile of Things. In Abramson, L. (Ed). “Mini Israel”, 70 Models, 45 Artists, One Space (pp. 148-156). Jerusalem: The Israel Museum.

Amit, D. (2009). Model of Jerusalem in the Second Temple Period. Jerusalem: The Israel Museum \& Holyland Tourism (1992) Ltd.

Avi-Yonah, M. (1966). A Short Guidebook to the Model of Jerusalem from the End of the Second Temple Period. Jerusalem: Holyland Corporation.

Balakirsky Katz, M. (2011). Avi Yonah's Model of Second Temple Jerusalem and the Development of Israeli Visual Culture. In Fine, S. (Ed). The Temple of Jerusalem: From Moses to the Messiah (pp. 349-364). Leiden: Brill.

Be'er, Y. (2013). Dangerous Liaison: The Dynamics of the Rise of the Temple Movements and Their Implications. (Report). Retrieved from Ir Amim website: http://www.ir-amim.org.il/en.

Black, M. (1962). Models and Metaphors: Studies in Language and Philosophy, Ithaca, New York: Cornell University Press.

Brabant, M. (2001, February 5). Jewish Fury at the 'Holy Land' Park. Retrieved from BBC News, http://news.bbc.co.uk.

Branham, J. R. (2008). The Temple that Won't Quit: Constructing sacred space in Orlando's Holy Land Experience theme park. Harvard Divinity Bulletin, pp. $18-31$.

Brown, B. (2001). Thing Theory. Critical Inquiry, Vol. 28, No.1, pp. 1-22.

Bruckner, D. (2010, November 19). A Dream Coming True. Makor Rishon, Shabbat Magazine (Hebrew). Retrieved from https://musaf-shabbat.com

Casanova, J. (2001). Religion, the New Millennium, and Globalization. Sociology of Religion, 62:4 pp. 415-441.

Cherni, H. \& Tsafrir, Y. (2009). Creators of the Model. In Amit, D. Model of Jerusalem in the Second Temple Period (pp. 14-16). Jerusalem: The Israel Museum \& Holyland Tourism (1992) Ltd.

Cohen Hattab, K. \& Kerber J. (2004). Literature, Cultural Identity and the Limits of Authenticity: A Composite Approach. International Journal of Tourism 
Research, 6, pp. 57-73.

Cohen-Hattab, K. \& Shoval, N. (2015). Tourism, Religion and Pilgrimage in Jerusalem. London: Routledge.

Culler, J. (1988). Framing the Sign: Criticism and its Institutions. Oxford: Basil Blackwell.

Lavie, Z. (1964 November 20). Built Jerusalem, Maariv, p. 35.

Liebman, C. S. and Don-Yehiya E. (1983). Civil Religion in Israel: Traditional Judaism and Political Culture in the Jewish State. Berkeley: University of California Press.

Long, B. O. (2003). Imagining the Holy Land: Maps, Models and Fantasy Travels. Bloomington: Indiana University Press.

MacCannell, D. (1976). The Tourist: A New Theory of the Leisure Class. New York: Schocken Books.

MacKey, R. (2010, July 22). Rebuilding Solomon's Temple in Sao Paulo. New York Times. Retrieved from https://www.nytimes.com

Morrison, T. (2013). The Built Narrative as Architectural History. The international Journal of Literary Humanities, Volume 10, issue 1, pp. 1-21.

Padan, Y. (2017a). Modelscapes of Nationalism: Collective Memories and Future Visions. Amsterdam: Amsterdam University Press.

Padan, Y. (2017b). Moving the Second Temple. In Hazan, N. (Ed), The Mount, the Dome and the Gaze: the Temple Mount in Israeli Visual Culture (pp. 91-99). Tel Aviv: Tel Aviv University.

Persico, T. (2017). The End Point of Zionism: Ethnocentrism and the Temple Mount. Israel Studies Review, Volume 32, Issue 1, pp. 104-122

Philips, T. (2010, July 21). Solomon's Temple in Brazil would put Christ the Redeemer in the shade. The Guardian. Retrieved from https://www.theguardian.com

Reiter, Y. (2001). Holiness and Politics in the Temple Mount's History. In Reiter, Y. (Ed). Sovereignty of God and Man: Sanctity and Political Centrality on the Temple Mount (pp. 5-20). Jerusalem: The Jerusalem Institute for Israel Studies.

Ribon, N. (1965, April 2). Next Year-Jerusalem is Built. Haaretz, p. 24.

Romero, S. (2014, July 24). Temple in Brazil Appeals to a Surge in Evangelicals. New York Times. Retrieved from https://www.nytimes.com. 
Seroussi, B. (2014). Inferno. In $31^{a}$ Bienal de São Paulo, Guia da exposição [31st Biennale of Sao Paulo, Exhibition Guide]. English translation retrieved from http://www.bienal.org.br/texto.php?i=1136

Silberman, N. A. (2001). If I forget Thee, O Jerusalem: Archaeology, Religious Commemorations and Nationalism in a Disputed City, 1801-2001. Nations and Nationalism, 7(4), pp. 487-504.

Simmons, S. (2010, August 31). New Aish Center at the Western Wall. Retrieved from Aish HaTorah website: http://www.aish.com/ci/s/78061807.html

Spalding, J. (2002 July 3-10). Authentic Replica. Christian Century, p. 14.

Stevenson, J. (2013). Sensational Devotion: Evangelical Performance in TwentyFirst-century America. Ann Arbor: The University of Michigan Press.

Stewart, S. (1993). On Longing: Narratives of the Miniature, the Gigantic, the Souvenir, the Collection. Baltimore: The Johns Hopkins University Press.

Tsafrir, Y. (2009). Introduction. In Amit, D. Model of Jerusalem in the Second Temple Period (pp. 9-13). Jerusalem: The Israel Museum \& Holyland Tourism (1992) Ltd.

Tuan, Y. F. (1976) Geopiety: a theme in man's attachment to nature and to place. In D. Lowenthal and Martyn Bowden (eds.), Geographies of the Mind (pp. 1139). New York: Oxford University Press.

Usborne, D. (2001, February 5). Jewish protesters to picket 'holy land' rival to Disney theme park. The Independent. Retrieved from https://www.independent.co.uk

Watts, J. (2014, October 1). Brazil's evangelicals become a political force to be reckoned with. The Guardian. Retrieved from https://www.theguardian.com Wharton, A. J. (2006). Selling Jerusalem: Relics, Replicas, Theme Parks. Chicago: The University of Chicago Press.

\footnotetext{
' For a detailed analysis of this model, see Padan, 2017a.

ii See for example Abramson, 2006; Amit, 2009; Avi-Yonah, 1966; Cohen Hattab and Kerber, 2004; Tsafrir 2009.

iii For a detailed analysis of this model, see Padan 2017b.
} 
iv For example: The Hebrew Music Museum, The Temple Institute, the Mikdash Educational Center.

${ }^{\vee}$ A non-profit educational and religious organization that promotes the building of the Third Temple instead of the Mosques on the Temple Mount: 'Our short-term goal is to rekindle the flame of the Holy Temple in the hearts of mankind through education. Our long-term goal is to do all in our limited power to bring about the building of the Holy Temple in our time'. Temple Institute website: https://www.templeinstitute.org vi Padan, 2017b.

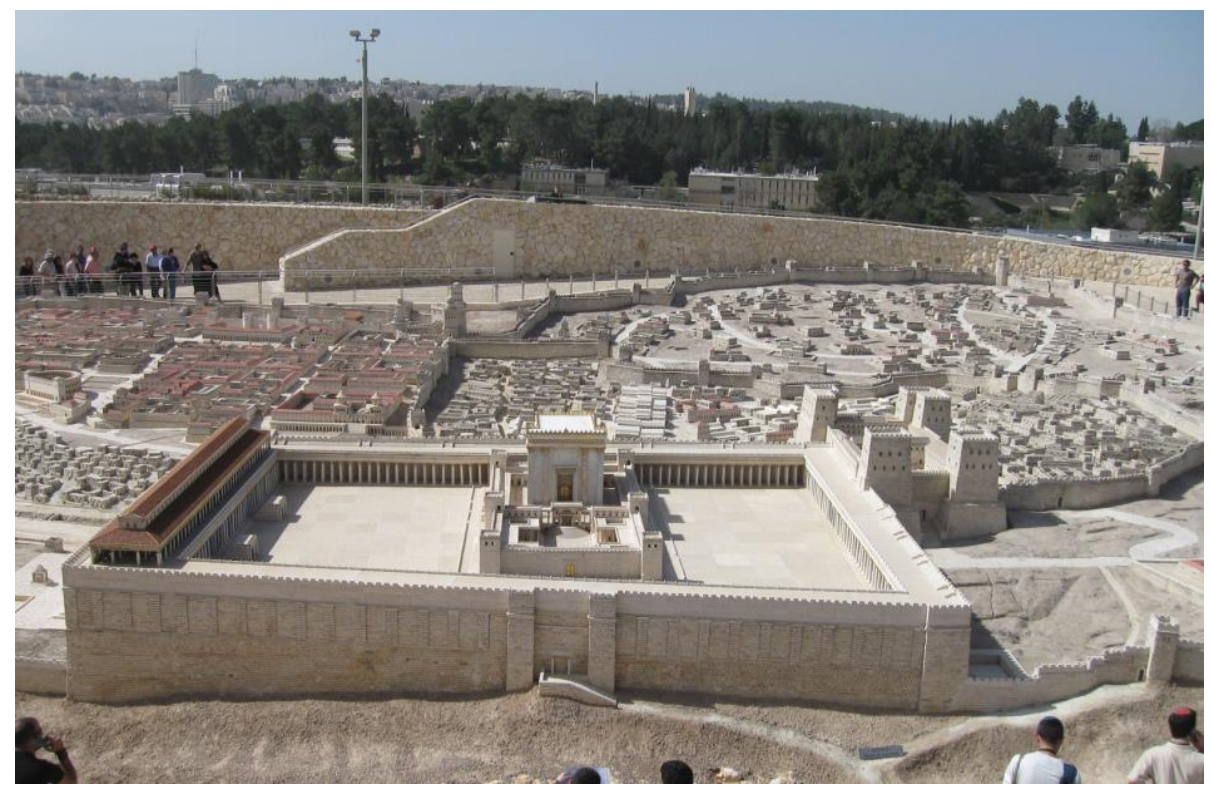

Fig. 1: The Holyland Model at the Israel Museum, Jerusalem, with the Temple in the foreground. Photo: Yael Padan

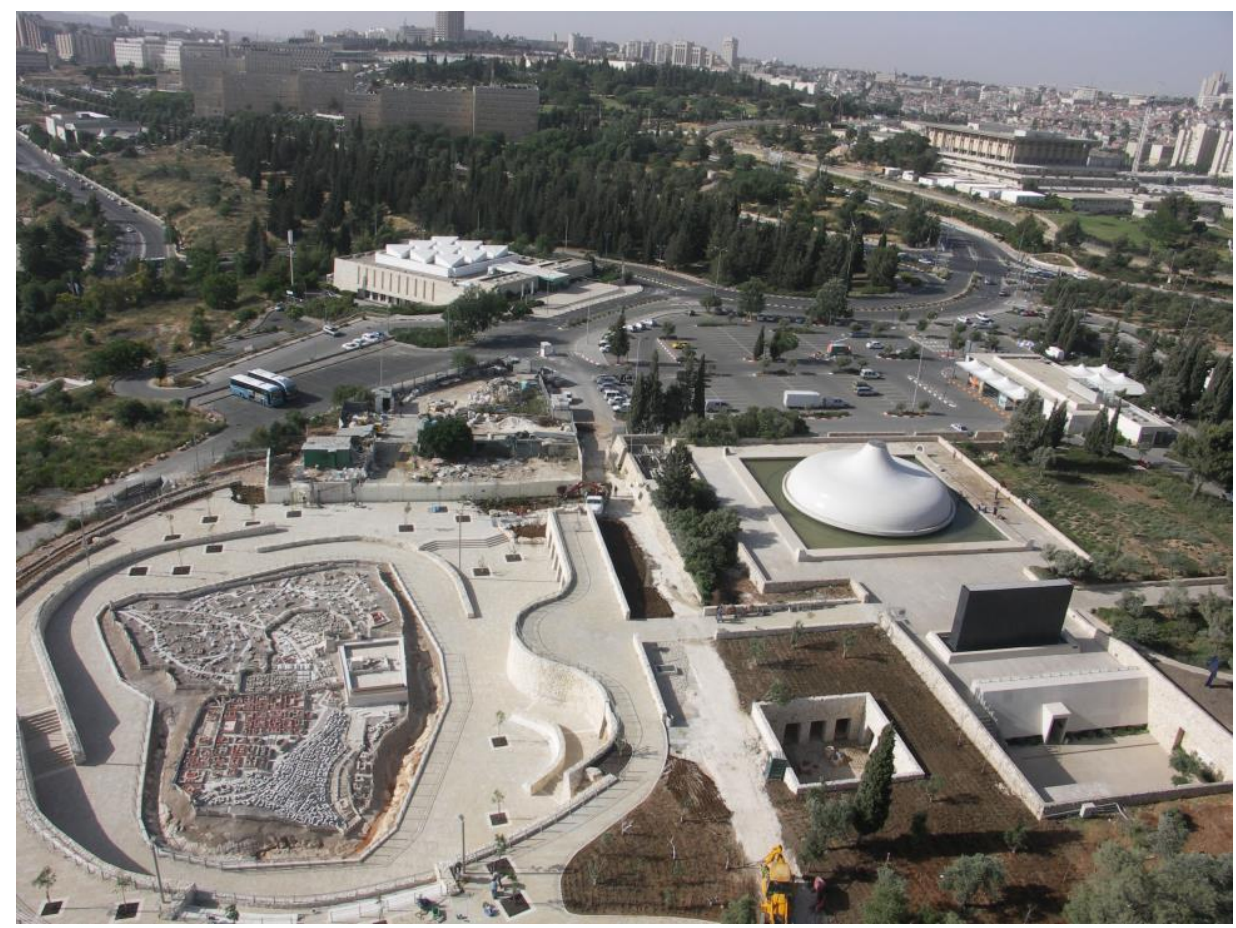


Fig. 2: The Holyland Model at the Israel Museum, Aerial view. Photo: @The Israel Museum, Jerusalem, by SKY BALLOONS.

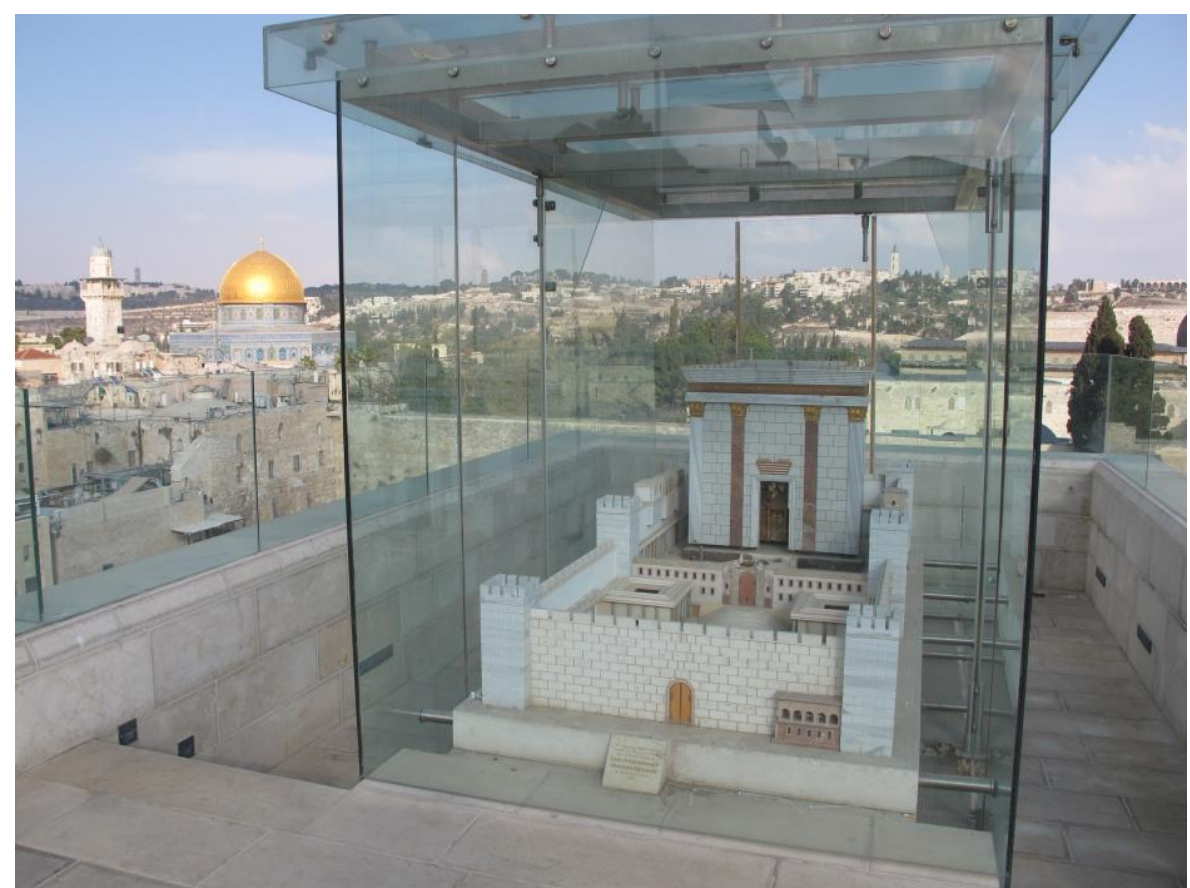

Fig. 3: The Second Temple Model on the roof of Aish HaTorah Yeshiva, Jerusalem. Photo: Anat Padan.

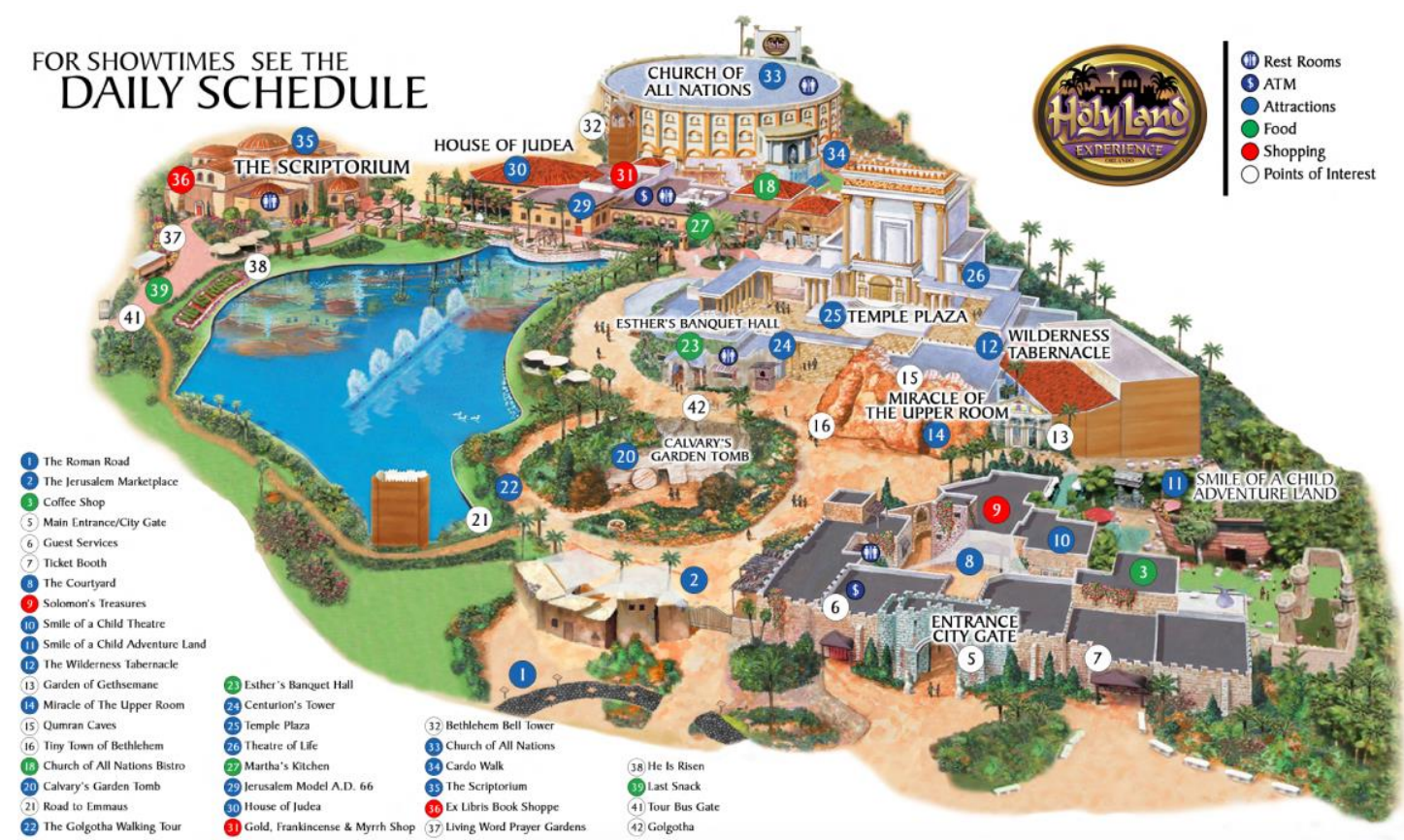

Fig. 4: The Holy Land Experience, map of the park (https://holylandexperience.com/park-map-directions/). 


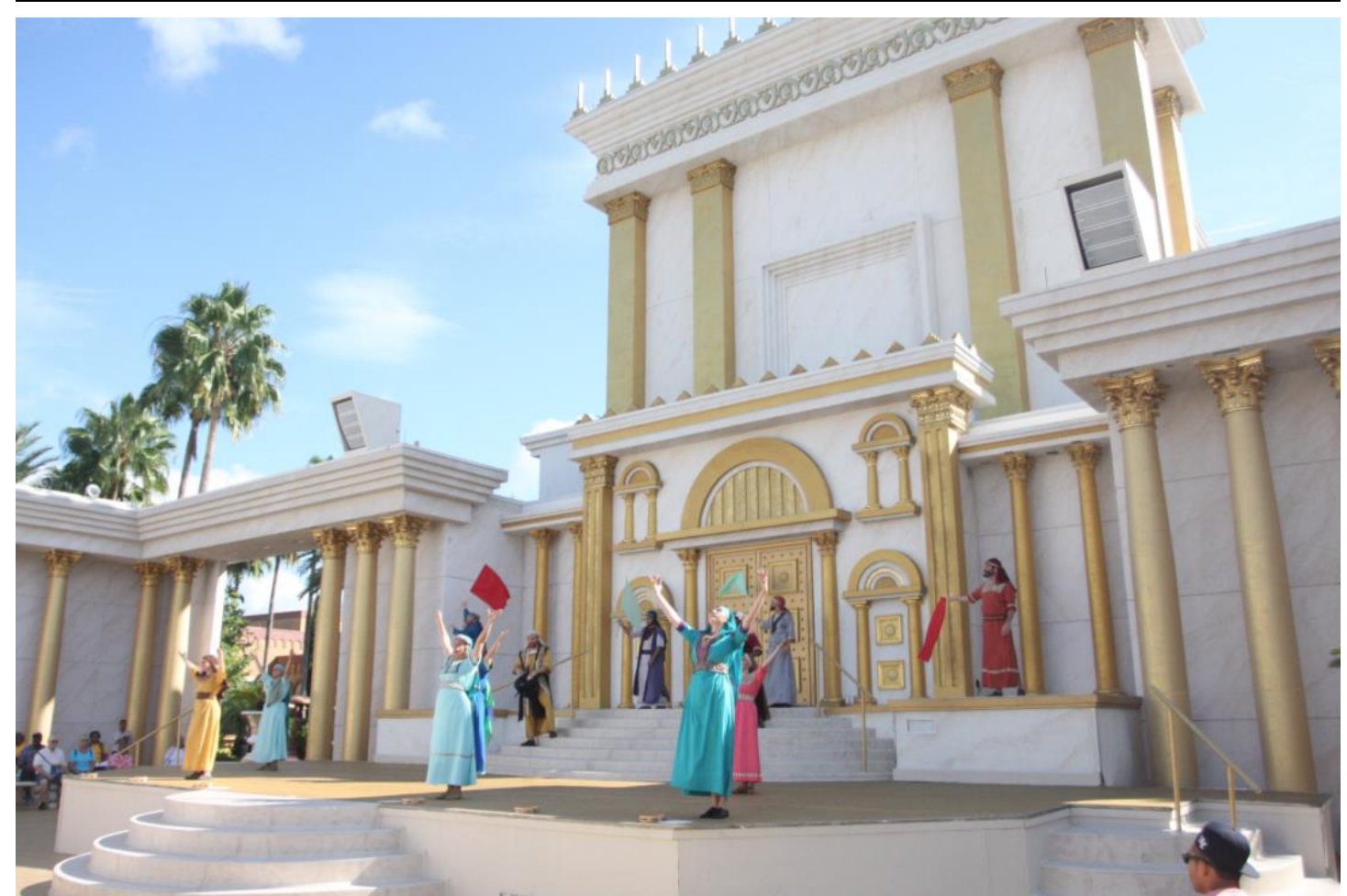

Fig. 5: The Holy Land Experience: the Great Temple

(https://holylandexperience.com/exhibit/the-great-temple/).

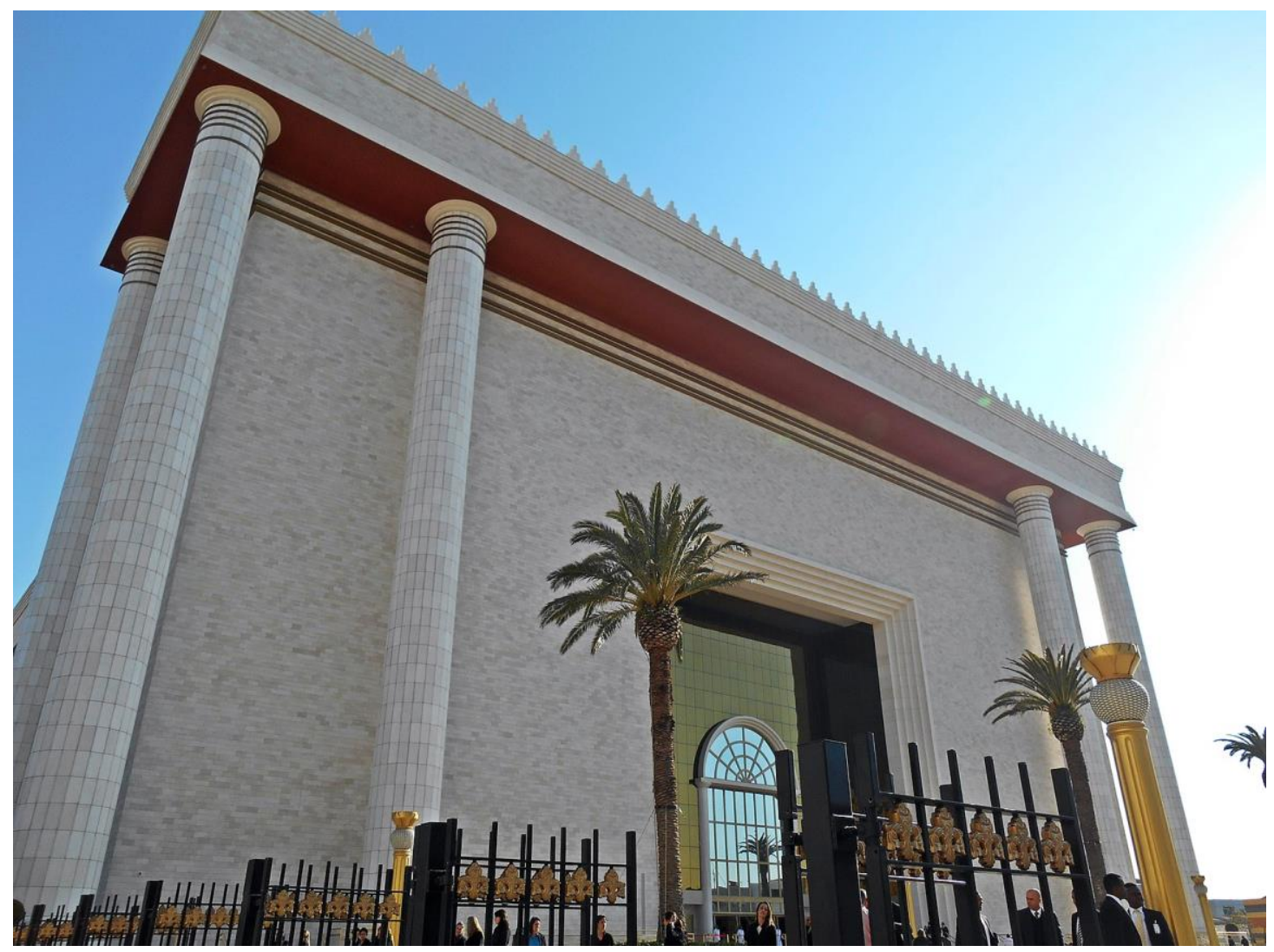

Fig. 6: Solomon's Temple, Sao Paulo. Photograph: Vitor Mazuco

(https://commons.wikimedia.org/wiki/File:Templo_de_Salomão_1.JPG\#globalusag) 